\title{
Front Matter: Volume 11551
}

, "Front Matter: Volume 11551," Proc. SPIE 11551, Holography, Diffractive Optics, and Applications X, 1155101 (3 November 2020); doi:

10.1117/12.2585946

SPIE. Event: SPIE/COS Photonics Asia, 2020, Online Only 


\title{
PROCEEDINGS OF SPIE
}

\section{Holography, Diffractive Optics, and Applications $X$}

\section{Yunlong Sheng Changhe Zhou Liangcai Cao Editors}

\section{2-16 October 2020} Online Only, China

\author{
Sponsored by \\ SPIE \\ COS-Chinese Optical Society
}

\section{Cooperating Organizations}

Tsinghua University (China) • Peking University (China) • University of Science and Technology of China (China) • Zhejiang University (China) • Tianjin University (China) Beijing Institute of Technology (China) • Beijing University of Posts and Telecommunications (China) • Nankai University (China) • Changchun University of Science and Technology (China) • University of Shanghai for Science and Technology (China) • Capital Normal University (China) • Huazhong University of Science and Technology (China) • Beijing Jiaotong University (China) • China Jiliang University (China) • Shanghai Institute of Optics and Fine Mechanics, CAS (China) • Changchun Institute of Optics, Fine Mechanics and Physics, CAS (China) - Institute of Semiconductors, CAS (China) - Institute of Optics and Electronics, CAS (China) • Institute of Physics, CAS (China) • Shanghai Institute of Technical Physics, CAS (China) • China Instrument and Control Society (China) • Japan Optical Society (Japan) • Korea Optical Society (Korea, Republic of) • Australia Optical Society (Australia) • Singapore Optical Society (Singapore) • European Optical Society

\section{Supporting Organizations}

China Association for Science and Technology (CAST) (China)

Department of Information of National Nature Science Foundation, China (NSFC) (China)

Published by

SPIE

Volume 11551 
The papers in this volume were part of the technical conference cited on the cover and title page. Papers were selected and subject to review by the editors and conference program committee. Some conference presentations may not be available for publication. Additional papers and presentation recordings may be available online in the SPIE Digital Library at SPIEDigitalLibrary.org.

The papers reflect the work and thoughts of the authors and are published herein as submitted. The publisher is not responsible for the validity of the information or for any outcomes resulting from reliance thereon.

Please use the following format to cite material from these proceedings:

Author(s), "Title of Paper," in Holography, Diffractive Optics, and Applications X, edited by Yunlong Sheng, Changhe Zhou, Liangcai Cao, Proceedings of SPIE Vol. 11551 (SPIE, Bellingham, WA, 2020) Seven-digit Article CID Number.

ISSN: 0277-786X

ISSN: 1996-756X (electronic)

ISBN: 9781510639171

ISBN: 9781510639188 (electronic)

Published by

SPIE

P.O. Box 10, Bellingham, Washington 98227-0010 USA

Telephone +1 3606763290 (Pacific Time) · Fax +1 3606471445

SPIE.org

Copyright (c) 2020, Society of Photo-Optical Instrumentation Engineers.

Copying of material in this book for internal or personal use, or for the internal or personal use of specific clients, beyond the fair use provisions granted by the U.S. Copyright Law is authorized by SPIE subject to payment of copying fees. The Transactional Reporting Service base fee for this volume is $\$ 21.00$ per article (or portion thereof), which should be paid directly to the Copyright Clearance Center (CCC), 222 Rosewood Drive, Danvers, MA 01923. Payment may also be made electronically through CCC Online at copyright.com. Other copying for republication, resale, advertising or promotion, or any form of systematic or multiple reproduction of any material in this book is prohibited except with permission in writing from the publisher. The CCC fee code is $0277-$ $786 \times / 20 / \$ 21.00$.

Printed in the United States of America by Curran Associates, Inc., under license from SPIE.

Publication of record for individual papers is online in the SPIE Digital Library.

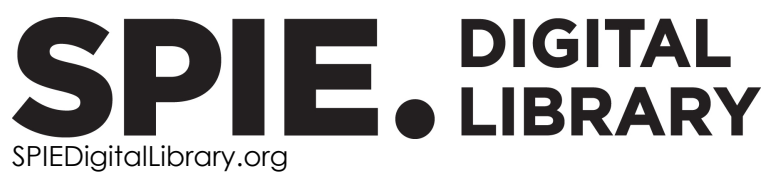

Paper Numbering: Proceedings of SPIE follow an e-First publication model. A unique citation identifier (CID) number is assigned to each article at the time of publication. Utilization of CIDs allows articles to be fully citable as soon as they are published online, and connects the same identifier to all online and print versions of the publication. SPIE uses a seven-digit CID article numbering system structured as follows:

- The first five digits correspond to the SPIE volume number.

- The last two digits indicate publication order within the volume using a Base 36 numbering system employing both numerals and letters. These two-number sets start with $00,01,02,03,04$, 05, 06, 07, 08, 09, OA, OB ... 0Z, followed by 10-1Z, 20-2Z, etc. The CID Number appears on each page of the manuscript. 


\section{Contents}

HOLOGRAPHY IN ARTIFICIAL INTELLIGENCE I

1155103 Holographic optical elements for augmented reality systems (Invited Paper) [11551-2]

1155106 On the use of deep learning for single-pixel imaging [11551-68]

HOLOGRAPHY IN ARTIFICIAL INTELLIGENCE II

1155108 Restore multiple particles by using short-path U-net model with average pooling based on digital holography [11551-6]

11551 OA Digital holography with deep learning and generative adversarial networks for automatic microplastics classification [11551-8]

$11551 \mathrm{OB}$ Model-based network architecture for image reconstruction in lensless imaging [11551-9]

HOLOGRAPHY WITH PLASMONIC STRUCTURES

$11551 \mathrm{OF} \quad$ Based on variation of refractive index active-tuned far-field plasmonic lens with doublediffraction for potential application of achromatic three-dimensional (3D) display [11551-13]

PICOMETER SCALE AND HIGH-SENSITIVE METROLOGY

11551 ol Picomicroscopy (Invited Paper) [11551-16]

11551 0J Simulation analysis of digital acousto-optic holography for internal structural inspection (Invited Paper) [11551-17]

$11551 \mathrm{OL} \quad$ Measuring fabrication errors of computer-generated holograms using embedded microgratings [11551-19]

DIGITAL HOLOGRAPHY

11551 OM Multidimensional digital holographic microscopy based on computational coherent superposition for coherent and incoherent light sensing (Invited Paper) [11551-20]

11551 OP Riesz transform for fringes pattern analysis: advantages and limitations [1 1551-23] 
$115510 Z$ EPISM-based full-parallax holographic stereogram: principle, modeling, and optimization (Invited Paper) [11551-36]

$1155111 \quad$ Holographic three-dimensional display based on shifted Fraunhofer diffraction [11551-38]

1155113 Investigation on characteristics of multi-beam interference pattern for 3D structuredillumination incoherent holographic imaging [11551-40]

\section{COMPUTER-GENERATED HOLOGRAMS AND SPATIAL LIGHT MODULATORS}

1155116 Volumetric graphics of microbubbles (Invited Paper) [11551-44]

11551 1A A holographic method for generating axial cosinoidal structured light using spatial light modulator [11551-48]

\section{POSTER SESSION}

11551 1B Three-dimensional anti-counterfeiting method based on reflective volume holography [11551-41]

11551 1C Approach for finding amplitudes of the transmitted diffraction orders in the framework of a rigorous coupled-wave analysis and its application in the study of three-layer sawtooth microstructures [11551-49]

11551 1D Design of 2-layer transmission grating with high efficiency, large bandwidth and great dispersion [11551-50]

$11551 \mathrm{lE} \quad$ Research on grating signal processing based on DSP [11551-51]

$11551 \mathrm{IF} \quad$ Polarization imaging of a sinusoidal amplitude grating with partially polarized and partially coherent light [11551-52]

$11551 \mathrm{lH} \quad$ Large-field holographic projection system based on deep-learning acceleration calculation [11551-54]

$1155111 \quad$ Polarization effects in interferometric testing with $\mathrm{f} / 1$ diffractive transmission sphere [1 1551-55]

$115511 \mathrm{~K}$ Improvement and denoising for dual-wavelength digital holographic microscopy [11551-57]

$11551 \mathrm{lL} \quad$ Optimization of high-resolution reconstruction algorithm for off-axis digital holographic imaging [11551-58] 
11551 1N Determination of linewidth for metal/oxide gratings by measured diffraction efficiency in several orders [11551-60]

1155110 Dry method for the formation of reflective phase DOEs using direct laser writing on thin Zr films [1 1551-61]

$115511 Q \quad$ Comparison of polarization-controllable multifocal arrays generated by radially and azimuthally polarized beams [11551-63]

11551 1R Simulation calculation of diffraction intensity of non-equal period grating [11551-64]

$115511 \mathrm{~T} \quad$ Singular skeleton in speckle field [11551-66]

$115511 \mathrm{U} \quad$ Phase unwrapping with the convolutional neural network [11551-67] 
Proc. of SPIE Vol. 11551 1155101-6

Downloaded From: https://www.spiedigitallibrary.org/conference-proceedings-of-spie on 26 Apr 2023 Terms of Use: https://www.spiedigitallibrary.org/terms-of-use 